\title{
Occurrence and characterization of methicillin- resistant staphylococci from bovine mastitis milk samples in Finland
}

Veera Gindonis ${ }^{1 *}$, Suvi Taponen ${ }^{1}$, Anna-Liisa Myllyniemi ${ }^{2}$, Satu Pyörälä ${ }^{3}$, Suvi Nykäsenoja ${ }^{2}$, Saara Salmenlinna ${ }^{4}$, Laura Lindholm ${ }^{5}$ and Merja Rantala ${ }^{6}$

\begin{abstract}
Background: Methicillin-resistant staphylococci (MRS) are increasingly being isolated in bovine mastitis. The aim of our study was to evaluate the occurrence of MRS in Finnish mastitis milk samples and characterize the MRS isolates using molecular methods.

Results: Methicillin-resistant S. aureus (MRSA) was a rare finding in bovine mastitis in Finland. Only two out of 135 $(1.5 \%)$ S. aureus isolates were positive for mec genes. One of these carried mecA and was of spa type t172, SCCmec type IV and ST375, and the other harboured mecC, being spa type t3256, and ST130. MRSA ST375 is common among human MRSA isolates in Finland, but this is the first report in the country of bovine mecC MRSA. In coagulase-negative staphylococci (CoNS) originating from bovine mastitis, methicillin resistance was more common. In the two CoNS collections studied, 5.2\% (17/324) and 1.8\% (2/110) of the isolates were mecA positive. Eighteen of these were methicillin-resistant S. epidermidis (MRSE), which were divided into 6 separate PFGE clusters. One pulsotype was detected in different parts of the country, indicating clonal spread. Most MRSE (13/18) were of SCCmec type IV, one was of type $V$ and four were non-typeable. Comparison with a human staphylococcal database indicated that bovine MRSE strains were not closely related to human MRSE isolates.

Conclusions: The occurrence of MRS, especially MRSA, in bovine mastitis in Finland was low. Most methicillinresistant bovine CoNS are MRSE, and we found evidence of a bovine MRSE strain that may spread clonally. This is the first report of a Finnish bovine isolate of MRSA mecc ST130. The study provides a baseline for further MRS monitoring.
\end{abstract}

Keywords: Staphylococci, Methicillin resistance, SCCmec, Bovine, Mastitis, mecA, mecC

\section{Background}

Staphylococci are common etiological agents of bovine mastitis. Infections caused by methicillin-resistant staphylococci (MRS) are more difficult to treat and may pose a public health risk [1]. Methicillin-resistant Staphylococcus aureus (MRSA) was first reported in cows in 1972, when Devriese and co-workers found 5.2\% of Belgian dairy farms MRSA positive [2]. Thirty years later, MRSA became a sporadically reported finding from bovine mastitis [3]. MRSA mainly spreads clonally.

\footnotetext{
* Correspondence: veera.gindonis@helsinki.fi

${ }^{1}$ Faculty of Veterinary Medicine, Department of Production Animal Medicine, University of Helsinki, Koetilantie 7, 00014 Helsinki, Finland

Full list of author information is available at the end of the article
}

Some MRSA isolates from bovine mastitis are thought to be bovine and some of human origin $[4,5]$. Clonal transmission between farmers and dairy cows has been shown to occur [1]. More recently, livestock-associated MRSA (LA-MRSA) strains of MRSA ST398 and strains carrying MRSA $_{\text {mec }}$ have emerged in humans [5-7]. These have also been isolated in bovine mastitis $[5,8]$. MRSA ST398 has been suggested to have developed in humans as a methicillin-sensitive $S$. aureus (MSSA) strain that was transferred to livestock, first to pigs and then to cattle, and acquired the mecA gene [9]. $\mathrm{MRSA}_{\text {mecC }}$, however, was first found in both human and bovine samples in 2011, and several different sequence type lineages of $\mathrm{MRSA}_{\text {mec }}$ have been recognized [5,10].

\section{Biomed Central}

(c) 2013 Gindonis et al.; licensee BioMed Central Ltd. This is an Open Access article distributed under the terms of the Creative Commons Attribution License (http://creativecommons.org/licenses/by/2.0), which permits unrestricted use, distribution, and reproduction in any medium, provided the original work is properly cited. 
Methicillin-resistant coagulase-negative staphylococci (MR-CoNS) have also been isolated in bovine mastitis [11-14]. They may be either species such as $S$. epidermidis or S. haemolyticus, which are commonly encountered in both human and animal specimens, or species that are mainly associated with bovine mastitis, such as S. simulans or S. chromogenes [12,13]. In particular, methicillin-resistant S. epidermidis (MRSE) has been a common finding: two recent studies from the Netherlands and the USA reported that over 30\% of $S$. epidermidis isolated in bovine mastitis were MRSE $[13,14]$. In a German study, eight out of $14 \mathrm{~S}$. epidermidis were MRSE [12]. There is evidence of clonal transmission of MR-CoNS between humans and dairy cows [15], and MRSE has been thought to spread clonally within a herd of dairy cows [14].

Methicillin resistance in staphylococci is due to penicillin-binding protein $2 \alpha(\mathrm{PBP} 2 \alpha)$, which is encoded by mec genes. The mec genes are embedded in large mobile elements called SCCmec (staphylococcal cassette chromosome mec) [16], which also carry a cassette chromosome recombinase ( $c c r$ ) gene complex and J regions (joining regions J1-J3) [17]. To date, 11 different classes (I-XI) of SCCmec in MRSA have been reported, and these are further divided into subtypes according to variations in the J regions [18]. At least classes I-V and XI of MRSA, and classes III-V of MR-CoNS, along with several variants, have been isolated in bovine mastitis $[4,5,12,19-21]$. MR-CoNS generally carry a vast variety of SCCmec elements and are currently considered to be the likely reservoir of the different types of mecA gene in MRSA [22].
The aim of this study was to 1) estimate the occurrence of MRS in bovine mastitis in Finland, 2) characterize the MRS isolates collected from bovine mastitis, and 3) compare them with available human isolates.

\section{Methods}

\section{Bacterial isolates}

To investigate the occurrence of methicillin resistance in staphylococcal species isolated from bovine mastitis, three sets of bacterial isolates were included in the study: one collection of S. aureus (collection 1) and two collections of CoNS (collections 2 and 3) (Table 1). From each collection, one isolate per staphylococcal species per cow was included in the present study. In rare cases where two or more isolates of the same species of the same cow were available, the most resistant isolate was chosen. All isolates were confirmed to be staphylococci by their typical colonial appearance, a positive catalase test and staining as Gram-positive cocci in clusters. Preliminary differentiation between $S$. aureus and CoNS was performed using a tube coagulase test (BD BBL Rabbit Coagulase Plasma, Becton Dickinson, NJ, USA).

\section{Antimicrobial susceptibility testing}

Susceptibilities of the isolates were tested for penicillin, oxacillin, tetracycline, erythromycin, clindamycin, trimethoprim, chloramphenicol, vancomycin, gentamicin and ciprofloxacin by using a broth microdilution method (VetMIC ${ }^{\mathrm{Tm}}$, SVA, Sweden) according to the existing standards [23,24]. Oxacillin results for bacterial collection 2 were interpreted using a

Table 1 Collections of staphylococci isolated from bovine mastitis included in the study*

\begin{tabular}{|c|c|c|c|c|c|c|c|c|}
\hline Material & Origin & Year & $\begin{array}{c}\text { Isolates } \\
\text { n }\end{array}$ & $\begin{array}{c}\text { Farms } \\
\text { n }\end{array}$ & $\begin{array}{c}\text { OxaMIC = R } \\
\text { n }(\%)^{* * *}\end{array}$ & $\begin{array}{c}\text { MRS } \\
\text { isolates } \\
\mathrm{n}(\%)\end{array}$ & $\begin{array}{c}\text { MRS-positive } \\
\text { farms } \\
\text { n (\%) }\end{array}$ & $\begin{array}{l}\text { MRS } \\
\text { species }\end{array}$ \\
\hline $\begin{array}{l}\text { 1) S. aureus } \\
\text { isolates from the } \\
\text { Finnish Food } \\
\text { Safety Authority } \\
\text { (Evira) }\end{array}$ & $\begin{array}{l}\text { Subclinical and clinical } \\
\text { mastitis cases nationwide. }\end{array}$ & $2003-2008$ & 135 & 117 & $18(13.3)$ & $2(1.5)$ & $2(1.7)$ & MRSA \\
\hline $\begin{array}{l}\text { 2) CoNS isolates } \\
\text { from Bovine } \\
\text { Mastitis Survey } \\
\text { material } \\
\text { (Pitkälä et al., 2004) }\end{array}$ & $\begin{array}{l}\text { Subclinical and clinical } \\
\text { mastitis, randomized } \\
\text { sample of a nationwide } \\
\text { bovine mastitis survey. }\end{array}$ & 2001 & 324 & 179 & $34(10.5)$ & $17(5.2)$ & $16(8.9)$ & $\begin{array}{l}\text { All MRSE, } \\
2 \text { isolates } \\
\text { originating } \\
\text { from the } \\
\text { same farm }\end{array}$ \\
\hline $\begin{array}{l}\text { 3) CoNS isolates } \\
\text { from the } \\
\text { University } \\
\text { Ambulatory } \\
\text { Clinic** material } \\
\text { (Taponen et al., } \\
\text { 2006) }\end{array}$ & $\begin{array}{l}\text { Subclinical and clinical } \\
\text { mastitis, on-call area of } \\
\text { the University Ambulatory } \\
\text { clinic. }\end{array}$ & 1999-2002 & 110 & 57 & $6(5.5)$ & $2(1.8)$ & $2(3.5)$ & $\begin{array}{l}1 \text { MRSE } \\
1 \text { MR-S. } \\
\text { fleurettii }\end{array}$ \\
\hline
\end{tabular}

* All isolates have been selected from the collections so that there is only one isolate per staphylococcal species per cow.

** The Ambulatory Clinic of the Department of Production Animal Medicine, Faculty of Veterinary Medicine, University of Helsinki.

*** The resistance breakpoints used for oxacillin were $>2 \mu \mathrm{g} / \mathrm{ml}$ for bacterial collections 1 and 2 , and $>1 \mu \mathrm{g} / \mathrm{ml}$ for collection 3 (see text for details). 
Table 2 Characteristics of the methicillin-resistant S. epidermidis (MRSE) from bovine mastitis of the study ( $n=18$ )

\begin{tabular}{|c|c|c|c|c|c|c|}
\hline PFGE Cluster & Isolate no. & $\begin{array}{c}\text { Oxacillin MIC } \\
(\mu \mathrm{g} / \mathrm{ml})^{*}\end{array}$ & Antimicrobial resistance profile* & $\beta$-lactamase disk test & BlaZ gene & $\begin{array}{c}\text { SCCmec type } \\
\text { (ccr type, mec class) }\end{array}$ \\
\hline A & 658 & $>4$ & PEN, OXA & + & + & IV (2B) \\
\hline B & 1314 & $>4$ & PEN, OXA & - & + & NT (2 -) \\
\hline$C_{1}$ & 1018 & $>4$ & PEN, OXA, TET, ERY & + & + & IV (2B) \\
\hline$C_{1}$ & 1289 & 4 & PEN, OXA, TET & + & + & IV $(2 B)$ \\
\hline$C_{1}$ & 1439 & 4 & PEN, OXA, TET, CHL & + & + & IV (2B) \\
\hline$C_{1}$ & 1834 & $>4$ & PEN, OXA, TET & + & + & IV (2B) \\
\hline$C_{1}$ & 2156 & $>4$ & PEN, OXA, TET & + & + & IV (2B) \\
\hline$C_{1}$ & $28 \mathrm{VT}$ & $>4$ & PEN, OXA, TET & + & + & IV (2B) \\
\hline$C_{2}$ & 1532 & $>4$ & PEN, OXA, TET & + & + & IV (2B) \\
\hline$C_{3}$ & $1391^{* *}$ & 4 & PEN, OXA, TET & + & + & IV (2B) \\
\hline$C_{3}$ & $1409^{* *}$ & 4 & PEN, OXA, TET & + & + & IV (2B) \\
\hline $\mathrm{C}_{4}$ & 775 & $>4$ & PEN, OXA, TET & + & + & $V(5 C 2)$ \\
\hline$D_{1}$ & 641 & 4 & PEN, OXA, TET & + & + & IV (2B) \\
\hline$D_{1}$ & 1750 & $>4$ & PEN, OXA, TET & - & - & IV (2B) \\
\hline$D_{2}$ & 990 & $>4$ & PEN, OXA, TET & + & + & NT $(2,5 \mathrm{C} 2)$ \\
\hline $\mathrm{E}_{1}$ & 9 & 2 & PEN, OXA, TET, ERY & + & + & $\mathrm{NT}(2,5 \mathrm{~B})$ \\
\hline$E_{2}$ & 1222 & $>4$ & PEN, OXA, TET, ERY & + & + & NT $(--)$ \\
\hline $\mathrm{F}$ & 922 & $>4$ & PEN, OXA & + & + & IV (2B) \\
\hline
\end{tabular}

Penicillin PEN, oxacillin OXA, tetracycline/oxytetracycline TET, erythromycin ERY, chloramphenicol CHL.

* Based on the results from Pitkälä et al. 2004 (Survey material), except for isolate $28 \mathrm{VT}$, which is from the Ambulatory Clinic material.

** Isolates originated from the same farm.

NT Non-typeable using the method described.

resistance breakpoint of $>2 \mu \mathrm{g} / \mathrm{ml}$ (Table 2) [25]. EUCAST epidemiological breakpoints (www.eucast. org) were applied to all other susceptibility test results. Beta-lactamase production by MRS isolates was tested with Cefinase disks (BD BBL Paper Disk for the Detection of $\beta$-Lactamase Enzymes, Becton-Dickinson, NJ, USA).

\section{Extraction of DNA}

Chromosomal DNA for ribotyping and PCR was prepared either using a previously described method [26] or with the MasterPure Gram Positive DNA Purification Kit (Epicentre Biotechnologies, Illumina Inc., Madison, WI, USA), High Pure PCR Template Preparation Kit (Roche, Basel, Switzerland) or Easy-DNA Kit (Invitrogen, Life Technologies, CA, USA).

\section{Bacterial identification by nuc-PCR and ribotyping}

Identification of MRSA isolates to the species level was verified by PCR using primers specific for S. aureus thermostable nuclease, the nuc gene [27]. MRCoNS isolates were analysed with the $16 \mathrm{~S}$ and $23 \mathrm{~S}$ rRNA gene restriction fragment length polymorphism method (ribotyping), as described previously [28], and identified by comparison in a numerical similarity analysis of the ribotype patterns with a ribotype library using the BioNumerics 4.6 software package (Applied Maths, Kortrijk, Belgium).

\section{Detection of mecA, mecC, blaZ and PVL genes by PCR}

Staphylococci were tested for carriage of the mecA gene by mecA PCR [29] with MRSA ATCC 29213 as a positive control. The selection criteria for mecA screening were set to include all isolates exceeding the oxacillin resistance breakpoint, and in addition, to include a representative number other isolates, especially those having an oxacillin MIC near the breakpoint. As a result, we included $63 \mathrm{~S}$. aureus isolates (collection 1): all isolates having oxacillin $\mathrm{MIC} \geq 4 \mu \mathrm{g} / \mathrm{ml}$ $(\mathrm{n}=18) ; 80 \%$ of isolates having an oxacillin MIC of $2 \mu \mathrm{g} / \mathrm{ml}$ $(\mathrm{n}=36)$; and 9 isolates with low oxacillin MICs $(\leq 1 \mu \mathrm{g} / \mathrm{ml})$. According to oxacillin histograms of the CoNS collections, separation into susceptible and resistant populations was not clearly evident. Therefore, from collection 2 we screened 238 CoNS isolates as follows: all isolates with $\mathrm{MIC} \geq 4 \mu \mathrm{g} / \mathrm{ml}$ $(\mathrm{n}=34)$, as well as all isolates with MIC $=1-2 \mu \mathrm{g} / \mathrm{ml}(\mathrm{n}=200)$ and 4 isolates with lower MICs. Collection 3 was smaller and all CoNS isolates were therefore included for mecA PCR $(n=110)$.

All mecA-negative $S$. aureus and mecA-negative CoNS isolates with an oxacillin MIC of $>2 \mu \mathrm{g} / \mathrm{ml}(\mathrm{n}=42)$ were 
tested for the presence of the $m e c \mathrm{C}$ gene by using previously described primers for a 138 bp PCR product [10]. MRSA $_{\text {LGA251 }}$ was used as a positive control. The mecC PCR reaction mixture contained $0.2 \mu \mathrm{M}$ of both primers, $200 \mu \mathrm{M}$ of each deoxynucleoside triphosphate, $1 \times$ buffer, $1 \mathrm{U}$ of polymerase (DyNAzyme DNA Polymerase Kit, Finnzymes, Espoo, Finland), and $1 \mu \mathrm{l}$ of DNA template in a final volume of $50 \mu \mathrm{l}$. The PCR cycling conditions were as follows: initial denaturation at $94^{\circ} \mathrm{C}$ for $5 \mathrm{~min}$; 35 cycles of denaturation at $94^{\circ} \mathrm{C}$ for $30 \mathrm{~s}$, annealing at $58^{\circ} \mathrm{C}$ for $1 \mathrm{~min}$, and elongation at $72^{\circ} \mathrm{C}$ for $1 \mathrm{~min}$; and final elongation at $72^{\circ} \mathrm{C}$ for $10 \mathrm{~min}$. Positive $\mathrm{mecC}$ PCR results were confirmed by sequencing of the PCR product at the Institute of Biotechnology, University of Helsinki. The sequence data were analysed with CLC Main Workbench software (version 6.6.2, CLCbio, Aarhus, Denmark). All $m e c \mathrm{~A}$ - or mecC-positive isolates were considered truly methicillin resistant (MRSA or MR-CoNS) and were further tested for the blaZ gene by a previously described method [30]. S. aureus ATCC 29213 was used as a positive control and S. aureus ATCC 25923 as a negative control [31]. In addition, MRSA isolates were tested for the carriage of genes for Panton-Valentine leucocidin (PVL), $l u k S-P V$ and $l u k F-P V$ [32].

\section{SCCmec typing}

The SCCmec types of isolates were assigned according to two previously described multiplex PCRs, M-PCR1 and M-PCR2 [33], with slight modifications. M-PCR1 and M-PCR2 were carried out using 2U of DyNAzyme I and $2 \mathrm{U}$ of DyNAzyme EXT DNA polymerases (Finnzymes, Espoo, Finland), respectively. The amount of DNA template was $200 \mathrm{ng}$ in a final volume of $25 \mu \mathrm{l}$ in both multiplex PCRs. The following strains of $S$. aureus were used as positive controls: NCTC 10442 (ccr1 and mec product B), ATCC BAA-1720 (ccr2, mec product A), ATCC BAA-43 (ccr3), ATCC BAA-42 (ccr4) and JCSC 6944 (ccr5, mec product C2).

\section{Spa sequence typing and multilocus sequence typing (MLST) of MRSA}

The region encoding the Staphylococcus Protein A (spa) was amplified as previously described [34]. The gene product was sequenced and the repeat region was analysed using BioNumerics (version 6.5, Applied Maths, Belgium). MLST was performed as previously described [35]. Sequencing results were compared against the MLST database and the sequence types were determined (http://www.mlst.net).

\section{Pulsed-field gel electrophoresis}

MRSE isolates were genotyped by PFGE using a previously described method [36] with slight modifications: DNA fragments were separated on $1 \%$ agarose made in
$100 \mathrm{ml} 0.5 \times$ TBE (casting frame 14 by $13 \mathrm{~cm}$ ) by using a Chef DR III system (Bio-Rad, USA) with $2000 \mathrm{ml}$ of $0.5 \times$ TBE as the running buffer. PFGE patterns were analysed using Bionumerics software (version 5.10, Applied Maths, Belgium). For interpretation, a similarity cut-off of $80 \%$ and a difference of $\leq 6$ in PFGE patterns were used in assigning the isolates into clusters; identical patterns were considered as the same pulsotype, and a difference of 3-6 bands as subtypes of the same cluster [37]. The PFGE patterns of the bovine MRS isolates were compared with the human staphylococcal culture collection of the National Institute of Health and Welfare (THL).

\section{Results}

Two out of $135 \mathrm{~S}$. aureus isolates originating from bovine mastitis (1.5\%) were MRSA, one isolated in 2005 and the other in 2006 from different herds. Both MRSA strains had oxacillin MIC of $>16 \mu \mathrm{g} / \mathrm{ml}$. The MRSA strain isolated in 2005 was of spa type t172, SCCmec type IV, ST 375, which corresponds to the PFGE type FIN-4 [37]. It carried the blaZ gene and was PVL negative. In addition to oxacillin the strain was phenotypically resistant to penicillin and trimethoprim, but susceptible to other tested antimicrobials. The MRSA strain isolated in 2006 carried mecC instead of mecA, but was negative in blaZ PCR, although phenotypically it produced beta-lactamase. This strain was highly susceptible to all tested antimicrobials except penicillin and oxacillin. Sequencing verified the mecC PCR product to be identical to the $m e c \mathrm{C}$ of the MRSA LGA251 [5]. The strain was of the ST130 and spa type t3256, and was PVL negative. SCCmec of this strain was not recognised by the used method.

Seventeen out of 324 (5.2\%) CoNS isolates from the national mastitis survey (bacterial collection 2) were positive for mecA. All of them were ribotyped as $S$. epidermidis. In this collection, $21.5 \%$ of all S. epidermidis isolates (17/79) were MRSE. Based on the PFGE pattern analysis, the strains of MRSE could be divided into three clusters of 2, 10 and 3 isolates, and 3 singletons (Figure 1). Twelve isolates were of SCCmec type IV and one isolate was assigned to type V. Four isolates were non-typable: two of them carried both $\mathrm{ccr}$ products 2 and 5, and the two other did not carry any mec products recognized by the methods used. Five of the cluster 2 isolates were identical in PFGE (Figure 1), and they all possessed the type IV SCCmec cassette. When compared with human MRSE and MSSE (methicillin sensitive $S$. epidermidis) strains, no similarity over $83.9 \%$ was detected. In the samples collected at the Ambulatory Clinic (bacterial collection 3), 2 out of 110 (1.8\%) CoNS were resistant to methicillin. The isolates were identified 


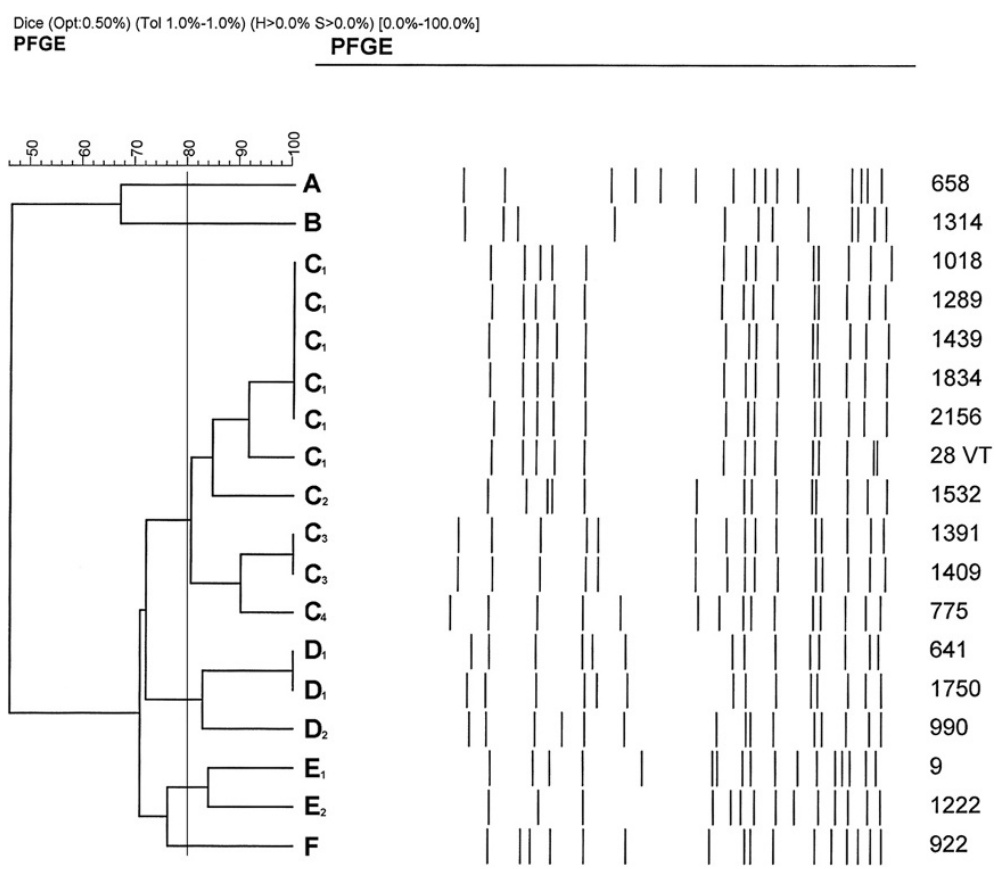

Figure 1 PFGE patterns of the MRSE strains isolated from bovine mastitis in Finland.

as $S$. epidermidis and $S$. fleurettii by ribotyping. Altogether, nine S. epidermidis isolates were recognised in collection 3. MRSE (isolate $28 \mathrm{VT}$ in Figure 1 and Table 2) was of SCCmec type IV and belonged to cluster C. S. fleurettii was non-typeable by the SCCmec protocol used.

No resistance to more than two classes of antimicrobials (multiresistance) was detected in the bovine MRSA, but four out of 18 MRSE of the study were multiresistant (Table 2).

\section{Discussion}

The occurrence of MRSA in the present study was low, totalling $1.6 \%$. However, $5.2 \%$ and $1.8 \%$ of the investigated CoNS isolates were mecA positive in bacterial collections 2 and 3, respectively. On the farm level, MRS occurred on $8.9 \%$ and $3.5 \%$ of the farms. These are expected results, as MR-CoNS are more common than MRSA [38]. In earlier studies, the occurrence of MRSA (percentage of $m e c A$-positive isolates out of all isolates in the given $S$. aureus collection) from bovine mastitis milk from Japan, Switzerland, Korea and Belgium has been $1.1 \%, 1.4 \%, 1.6 \%$ and $9.3 \%$, respectively $[8,11,20,39]$. The occurrence of MR-CoNS in previous studies has been between 1.6 and 13.5\% [11-14]. However, due to methodological differences, comparison between the studies is difficult.

The MRSA ST375 found in 2005 was of a type that is frequently isolated in human specimens in Finland [40], and it is likely to be of human origin. Human infections due to MRSA ST375 are usually community acquired and isolates of this clone are typically very susceptible to other antimicrobials except betalactams. This was also the case in our study. A follow-up study was performed in 2008 in the same farm where ST375 was first detected in 2005 (data not shown). Milk specimens as well as environmental specimens were collected. An identical MRSA ST375 was again detected in one of the milk specimens, but in addition, another MRSA strain was discovered from a separate milk specimen. The latter strain had the same spa type $\mathrm{t} 172$ as the previously identified MRSA ST375, but showed changes in the PFGE pattern and was thus classified as a subtype of FIN-4 by PFGE. Because in 2008 the cows on this farm were different from those sampled in 2005, the ST375 strain detected in the cows could have originated from the herd staff carrying the strain that evolved in them, and might have been re-transmitted to the susceptible cows over the years. Sampling of humans may have given additional information to the epidemiology of MRSA on the farm, but was not performed, as the people on the farm rejected further evaluation.

The MRSA $_{\text {mec }}$ t3256 ST130 found in the present study is of the same spa type as two other mecCcontaining MRSA isolates from Denmark [10]. Our strain was very susceptible to other antimicrobials, which has been also a common finding in earlier reports. $\mathrm{MecC}$-carrying MRSA strains have also previously been encountered in specimens from both humans and dairy cows in UK, Ireland and France [5,7,10,41]. A recent 
study revealed that $m e c \mathrm{C}$ carrying $S$. aureus strains belong usually to two distinct clonal lineages, CC 130 and CC 2361, but there are several distinct spa types [42]. Moreover, the results of the same study showed that human infections associated with $m e c \mathrm{C}$ MRSA are usually community acquired and often detected in humans living in rural area. There is also strong evidence that $m e c \mathrm{C}$ MRSA is transmitted between ruminants and humans [42,43]. The role of bovines and other ruminants in the epidemiology of these MRSA lineages in humans warrants further investigation. Sporadic cases of human MRSA $_{m e c C}$ have also been detected in Finland (THL, unpublished data), but molecular typing results were not yet available for comparison.

All but one of 19 MR-CoNS of the present study was MRSE. The occurrence of MRSE among S. epidermidis was lower than in previously published studies [12-14]. According to the PFGE results, the MRSE were assigned into six different clusters (Figure 1). Five out of ten cluster $\mathrm{C}$ isolates were identical in the PFGE, although they originated from different parts of the country and no common denominator could be seen. It seems possible that this pulsotype spreads clonally. No close match was found for the bovine strains of MRSE in the human staphylococcal database of THL. However, there is no continuous molecular surveillance of human MRSE, and the database only covers genotypes from a limited number of isolates obtained from hospitalized patients. One human MRSE isolate of the THL database had a similarity of $83.9 \%$ with the cluster F singleton MRSE 922 of the present study, and would therefore be classified as a subtype of cluster F. S. epidermidis is a common cause of hospital-acquired infections in humans, and the hospital-acquired strains are mostly resistant to methicillin [38]. Human isolates are often multiresistant, whereas the strains found in this study were susceptible to most classes of antimicrobials tested. This also suggests that cattle and humans harbour different strains of MRSE.

The SCCmec types IV and V found in the MRSE of the present study are considered as community-acquired SCCmec types in MRSA. Both types have previously been encountered in bovine MRSE isolates [12,44]. It is also common that MR-CoNS carry SCCmec elements that are non-typeable by the established methods [22]. SCCmec types of bovine MRSE seem to have variation like the isolates originating from humans [45], and bovine MRSE may spread clonally between dairy farms the same way as strains of MRSA and MRSE spread in humans.

MRSA ST375 and most MRSE in this study (17/18) carried the bla $Z$ gene encoding beta-lactamase, causing penicillin resistance. No blaZ gene was detected in the MRSA ST130 carrying the mecC gene, although it was phenotypically beta-lactamase positive. The most probable reason for a negative result in blaZ PCR is that this strain carries a divergent blaZ gene as described earlier in S. aureus LGA 251 type strain or other strains belonging to S. aureus clonal complex CC 130 with SCCmec XI $[5,7]$. These studies reported that in this particular SCCmec cassette the nucleotide sequences of the mec and genes regulating its function, $m e c I$ and $m e c R 1$, as well as sequences of the bla $\mathrm{Z}$ and $c c r$ genes have many differences compared to the respective genes carried by other SCCmec types. For instance, similarities of divergent blaZ gene sequence of the SCCmec XI are only between $44-68 \%$ at the protein level when compared to other staphylococcal beta-lactamase genes at the GenBank database (http://www.ncbi.nlm.nih.gov). The blaZ gene primers used in this study are not able to detect the blaZ gene variant of the SCCmec XI.

In many countries, mastitis is treated without bacteriological diagnosis. Currently, almost $80 \%$ of milk specimens from bovine mastitis in Finland are diagnosed by a commercial PCR test that identifies the bacteria in the specimen. For resistance, however, it only detects penicillin resistance mediated by the bla $\mathrm{Z}$ gene. Therefore, it is likely that cases of MRS mastitis mostly go unnoticed. These can, in fact, be incorrectly reported as penicillin susceptible, if staphylococci with divergent blaZ variant will emerge and the primers of the test in question are not covering the variant. Incorrect susceptibility information can lead to inappropriate treatment strategy that may, in part, select for already existing strains of MRS. Treatment with cephalosporins but also with other betalactams has been shown to select for MRSA in humans [46]. These antibiotics are commonly used in dairy cows. A reliable susceptibility testing method is therefore of the utmost importance. National Finnish recommendations for MRSA of animal origin [47] state that cows with MRSA should primarily be culled, the animal segregated or the infected quarters dried off to stop the MRSA from spreading to other cows and people. Methicillin resistance is still rare in Finnish CoNS of bovine origin, but MRSA-related management recommendations could also be applied to cows carrying MRSE. To detect changes in methicillin resistance in bovine staphylococci, regular national surveillance is needed.

\section{Conclusions}

The occurrence of MRS in dairy cows in Finland was low. The results of this study can be used as a baseline for further surveillance. According to our results, MRSE is the most likely MRS in bovine mastitis, but MRSA is expected to be a sporadic finding. MRSE can spread clonally among the bovine population. Of the two MRSA strains found in this study, MRSA ST375 is also common among human MRSA isolates in Finland. This 
is the first report of bovine MRSA ST 130 carrying the $m e c \mathrm{C}$ gene in our country.

Staphylococci isolated in bovine mastitis should be routinely tested for methicillin resistance. Surveys to reassess the situation should be conducted at regular intervals for early intervention and the prevention of epidemic strains from spreading in the population. Maintaining low prevalence of MRS mastitis in Finland may succeed through continuous education of veterinarians and farmers on the importance of reliable susceptibility testing, hygiene and judicious use of antibiotics.

\section{Competing interests}

The authors declare that they have no competing interests.

\section{Authors' contributions}

VG participated in the planning of the study, PCR, PFGE and ribotyping, and analysed the data and drafted the manuscript. ST participated in the planning of the study, performed ribotyping and participated in writing the manuscript. A-LM and SN provided isolates from the bacterial collection at Evira, carried out antimicrobial susceptibility testing, PCR, and SCCmec typing, SN also did MLST typing. SP participated in planning and coordination of the study, collection of isolates, and preparing the manuscript. SS participated in MLST typing, and together with LL helped with PFGE analysis and compared the isolates of the study with the respective human MRS strains from the reference laboratory database of THL. MR participated in analysing the data and preparing the manuscript and act as a supervisor of VG. All authors participated in preparing the manuscript, and read and approved the final manuscript.

\section{Acknowledgements}

We thank Dr Mark Holmes, University of Cambridge, UK, for kindly sharing the strain of MRSA ${ }_{L G A 251}$ and Dr Robert Skov from Statens Serum Institut, Copenhagen, Denmark, for the S. aureus strain JCSC 6944. We are also grateful to Dr Johanna Mäkinen, National Institute for Health and Welfare, for her assistance in processing the data, and to laboratory technician Taina Lehto for her indispensable technical assistance. Thomas Grönthal, DVM, is acknowledged for editorial assistance and Roy Siddall, PhD, for revising the English language of the manuscript. The Graduate School of the Faculty of Veterinary Medicine, Walter Ehrström Foundation and the Finnish Veterinary Foundation are gratefully acknowledged for funding this study.

\section{Author details}

${ }^{1}$ Faculty of Veterinary Medicine, Department of Production Animal Medicine, University of Helsinki, Koetilantie 7, 00014 Helsinki, Finland. ${ }^{2}$ Research and Laboratory Department, Food and Feed Microbiology Research Unit, Finnish Food Safety Authority Evira, Mustialankatu 3, 00790 Helsinki, Finland. ${ }^{3}$ Faculty of Veterinary Medicine, Department of Production Animal Medicine, University of Helsinki, Paroninkuja 20, 04920 Saarentaus, Finland. ${ }^{4}$ Department of Infectious Disease Surveillance and Control, National Institute for Health and Welfare, PO Box 30, 00271 Helsinki, Finland. ${ }^{5}$ Department of Infectious Disease Surveillance and Control, National Institute for Health and Welfare, PO Box 57, 20521 Turku, Finland. 'Faculty of Veterinary Medicine, Department of Equine and Small Animal Sciences, University of Helsinki, Viikintie 49, 00014 Helsinki, Finland.

Received: 13 February 2013 Accepted: 19 August 2013 Published: 28 August 2013

\section{References}

1. Juhasz-Kaszanyitzky E, Janosi S, Somogyi P, Dan A, van der Graaf-van Bloois L, van Duijkeren E, Wagenaar JA: MRSA transmission between cows and humans. Emerg Infect Dis 2007, 13:630-632.

2. Devriese LA, Van Damme LR, Fameree L: Methicillin (cloxacillin)-resistant Staphylococcus aureus strains isolated from bovine mastitis cases. Zentralb/ Veterinarmed B 1972, 19:598-605.
3. Lee JH: Methicillin (Oxacillin)-resistant Staphylococcus aureus strains isolated from major food animals and their potential transmission to humans. Appl Environ Microbiol 2003, 69:6489-6494.

4. Haenni M, Galofaro L, Ponsin C, Bes M, Laurent F, Madec JY: Staphylococcal bovine mastitis in France: enterotoxins, resistance and the human Geraldine methicillin-resistant Staphylococcus aureus clone. J Antimicrob Chemother 2011, 66:216-218.

5. Garcia-Alvarez L, Holden MT, Lindsay H, Webb CR, Brown DF, Curran MD, Walpole E, Brooks K, Pickard DJ, Teale C, Parkhill J, Bentley SD, Edwards GF, Girvan EK, Kearns AM, Pichon B, Hill RL, Larsen AR, Skov RL, Peacock SJ, Maskell DJ, Holmes MA: Meticillin-resistant Staphylococcus aureus with a novel mecA homologue in human and bovine populations in the UK and Denmark: a descriptive study. Lancet Infect Dis 2011, 11:595-603.

6. van Loo I, Huijsdens X, Tiemersma E, de Neeling A, van de Sande-Bruinsma N, Beaujean D, Voss A, Kluytmans J: Emergence of methicillin-resistant Staphylococcus aureus of animal origin in humans. Emerg Infect Dis 2007, 13:1834-1839.

7. Shore AC, Deasy EC, Slickers P, Brennan G, O'Connell B, Monecke S, Ehricht R, Coleman DC: Detection of staphylococcal cassette chromosome mec type XI carrying highly divergent mecA, mecl, mecR1, blaZ, and ccr genes in human clinical isolates of clonal complex 130 methicillin-resistant Staphylococcus aureus. Antimicrob Agents Chemother 2011, 55:3765-3773.

8. Huber H, Koller S, Giezendanner N, Stephan R, Zweifel C: Prevalence and characteristics of meticillin-resistant Staphylococcus aureus in humans in contact with farm animals, in livestock, and in food of animal origin, Switzerland, 2009. Euro Surveill 2010, 15:19542.

9. Price LB, Stegger M, Hasman H, Aziz M, Larsen J, Andersen PS, Pearson T, Waters AE, Foster JT, Schupp J, Gillece J, Driebe E, Liu CM, Springer B, Zdovc I, Battisti A, Franco A, Zmudzki J, Schwarz S, Butaye P, Jouy E, Pomba C, Porrero MC, Ruimy R, Smith TC, Robinson DA, Weese JS, Arriola CS, Yu F, Laurent F, Keim P, Skov R, Aarestrup FM: Staphylococcus aureus CC398: host adaptation and emergence of methicillin resistance in livestock. MBio 2012, 3:e00305-e00311.

10. Stegger M, Andersen PS, Kearns A, Pichon B, Holmes MA, Edwards G, Laurent F, Teale C, Skov R, Larsen AR: Rapid detection, differentiation and typing of methicillin-resistant Staphylococcus aureus harbouring either mecA or the new mecA homologue mecA(LGA251). Clin Microbiol Infect 2012, 18:395-400.

11. Moon JS, Lee AR, Kang HM, Lee ES, Kim MN, Paik YH, Park YH, Joo YS, Koo $\mathrm{HC}$ : Phenotypic and genetic antibiogram of methicillin-resistant staphylococci isolated from bovine mastitis in Korea. J Dairy Sci 2007, 90:1176-1185.

12. Fessler AT, Billerbeck C, Kadlec K, Schwarz S: Identification and characterization of methicillin-resistant coagulase-negative staphylococci from bovine mastitis. J Antimicrob Chemother 2010, 65:1576-1582.

13. Sampimon OC, Lam TJ, Mevius DJ, Schukken YH, Zadoks RN: Antimicrobial susceptibility of coagulase-negative staphylococci isolated from bovine milk samples. Vet Microbiol 2011, 150:173-179.

14. Sawant AA, Gillespie BE, Oliver SP: Antimicrobial susceptibility of coagulase-negative Staphylococcus species isolated from bovine milk. Vet Microbiol 2009, 134:73-81.

15. Thorberg BM, Kuhn I, Aarestrup FM, Brandstrom B, Jonsson P, Danielsson-Tham ML: Pheno- and genotyping of Staphylococcus epidermidis isolated from bovine milk and human skin. Vet Microbiol 2006, 115:163-172.

16. Katayama $Y$, Ito T, Hiramatsu K: A new class of genetic element, staphylococcus cassette chromosome mec, encodes methicillin resistance in Staphylococcus aureus. Antimicrob Agents Chemother 2000, 44:1549-1555.

17. International Working Group on the Classification of Staphylococcal Cassette Chromosome Elements (IWG-SCC): Classification of staphylococcal cassette chromosome mec (SCCmec): guidelines for reporting novel SCCmec elements. Antimicrob Agents Chemother 2009, 53:4961-4967.

18. Ito T, Hiramatsu K, Tomasz A, de Lencastre H, Perreten V, Holden MT, Coleman DC, Goering R, Giffard PM, Skov RL, Zhang K, Westh H, O'Brien F, Tenover FC, Oliveira DC, Boyle-Vavra S, Laurent F, Kearns AM, Kreiswirth B, Ko KS, Grundmann H, Sollid JE, John JF Jr, Daum R, Soderquist B, Buist G, on behalf of the International Working Group on the Classification of Staphylococcal Cassette Chromosome Elements (IWG-SCC): Guidelines for 
reporting novel mecA gene homologues. Antimicrob Agents Chemother 2012, 56:4997-4999.

19. Fessler A, Scott C, Kadlec K, Ehricht R, Monecke S, Schwarz S: Characterization of methicillin-resistant Staphylococcus aureus ST398 from cases of bovine mastitis. J Antimicrob Chemother 2010, 65:619-625.

20. Hata E, Katsuda K, Kobayashi H, Uchida I, Tanaka K, Eguchi M: Genetic variation among Staphylococcus aureus strains from bovine milk and their relevance to methicillin-resistant isolates from humans. J Clin Microbiol 2010, 48:2130-2139.

21. Wang XM, Zhang WJ, Schwarz S, Yu SY, Liu H, Si W, Zhang RM, Liu S: Methicillin-resistant Staphylococcus aureus ST9 from a case of bovine mastitis carries the genes cfr and erm $(A)$ on a small plasmid. J Antimicrob Chemother 2012, 67:1287-1289.

22. Hanssen AM, Sollid JU: Multiple staphylococcal cassette chromosomes and allelic variants of cassette chromosome recombinases in Staphylococcus aureus and coagulase-negative staphylococci from Norway. Antimicrob Agents Chemother 2007, 51:1671-1677.

23. CLSI: Performance standards for antimicrobial disk and dilution susceptibility tests for bacteria isolated from animals; approved standard, CLSI document M31-A3. 3rd edition. Wayne, PA: Clinical and Laboratory Standards Institute; 2008.

24. NCCLS: Performance standards for antimicrobial disc and dilution susceptibility tests for bacteria isolated from animals; approved standard, NCCLS document M31-A2. 2nd edition. Wayne, PA: National Committee for Clinical Laboratory Standards; 2002

25. Pitkälä A, Haveri M, Pyörälä S, Myllys V, Honkanen-Buzalski T: Bovine mastitis in Finland 2001-prevalence, distribution of bacteria, and antimicrobial resistance. J Dairy Sci 2004, 87:2433-2441.

26. Predari SC, Ligozzi M, Fontana R: Genotypic identification of methicillinresistant coagulase-negative staphylococci by polymerase chain reaction. Antimicrob Agents Chemother 1991, 35:2568-2573.

27. Brakstad OG, Aasbakk K, Maeland JA: Detection of Staphylococcus aureus by polymerase chain reaction amplification of the nuc gene. J Clin Microbiol 1992, 30:1654-1660.

28. Taponen S, Björkroth J, Pyörälä S: Coagulase-negative staphylococci isolated from bovine extramammary sites and intramammary infections in a single dairy herd. J Dairy Res 2008, 75:422-429.

29. Murakami K, Minamide W, Wada K, Nakamura E, Teraoka H, Watanabe S: Identification of methicillin-resistant strains of staphylococci by polymerase chain reaction. J Clin Microbiol 1991, 29:2240-2244.

30. Haveri M, Suominen S, Rantala L, Honkanen-Buzalski T, Pyörälä S Comparison of phenotypic and genotypic detection of penicillin $G$ resistance of Staphylococcus aureus isolated from bovine intramammary infection. Vet Microbiol 2005, 106:97-102.

31. Pitkälä A, Salmikivi L, Bredbacka P, Myllyniemi AL, Koskinen MT: Comparison of tests for detection of beta-lactamase-producing staphylococci. J Clin Microbiol 2007, 45:2031-2033.

32. Lina G, Piemont $Y$, Godail-Gamot F, Bes M, Peter MO, Gauduchon V, Vandenesch F, Etienne J: Involvement of Panton-Valentine leukocidinproducing Staphylococcus aureus in primary skin infections and pneumonia. Clin Infect Dis 1999, 29:1128-1132

33. Kondo Y, Ito T, Ma XX, Watanabe S, Kreiswirth BN, Etienne J, Hiramatsu K: Combination of multiplex PCRs for staphylococcal cassette chromosome mec type assignment: rapid identification system for mec, ccr, and major differences in junkyard regions. Antimicrob Agents Chemother 2007 51:264-274.

34. Shopsin B, Gomez M, Montgomery SO, Smith DH, Waddington M, Dodge DE, Bost DA, Riehman M, Naidich S, Kreiswirth BN: Evaluation of protein A gene polymorphic region DNA sequencing for typing of Staphylococcus aureus strains. J Clin Microbiol 1999, 37:3556-3563.

35. Enright MC, Day NP, Davies CE, Peacock SJ, Spratt BG: Multilocus sequence typing for characterization of methicillin-resistant and methicillinsusceptible clones of Staphylococcus aureus. J Clin Microbiol 2000, 38:1008-1015.

36. Murchan S, Kaufmann ME, Deplano A, de Ryck R, Struelens M, Zinn CE, Fussing V, Salmenlinna S, Vuopio-Varkila J, El Solh N, Cuny C, Witte W, Tassios PT, Legakis N, van Leeuwen W, van Belkum A, Vindel A, Laconcha I, Garaizar J, Haeggman S, Olsson-Liljequist B, Ransjo U, Coombes G, Cookson B: Harmonization of pulsed-field gel electrophoresis protocols for epidemiological typing of strains of methicillin-resistant Staphylococcus aureus: a single approach developed by consensus in 10 European laboratories and its application for tracing the spread of related strains. J Clin Microbiol 2003, 41:1574-1585.

37. Vainio A, Karden-Lilja M, Ibrahem S, Kerttula AM, Salmenlinna S, Virolainen A, Vuopio-Varkila J: Clonality of epidemic methicillin-resistant Staphylococcus aureus strains in Finland as defined by several molecular methods. Eur J Clin Microbiol Infect Dis 2008, 27:545-555.

38. Lyytikäinen O, Lumio J, Sarkkinen H, Kolho E, Kostiala A, Ruutu P, Hospital Infection Surveillance Team: Nosocomial bloodstream infections in Finnish hospitals during 1999-2000. Clin Infect Dis 2002, 35:e14-e19.

39. Vanderhaeghen W, Cerpentier T, Adriaensen C, Vicca J, Hermans K, Butaye P: Methicillin-resistant Staphylococcus aureus (MRSA) ST398 associated with clinical and subclinical mastitis in Belgian cows. Vet Microbiol 2010, 144:166-171.

40. Kanerva M, Salmenlinna S, Vuopio-Varkila J, Lehtinen P, Möttönen T, Virtanen MJ, Lyytikäinen O: Community-associated methicillin-resistant Staphylococcus aureus isolated in Finland in 2004 to 2006. J Clin Microbiol 2009, 47:2655-2657.

41. Laurent F, Chardon H, Haenni M, Bes M, Reverdy ME, Madec JY, Lagier E, Vandenesch F, Tristan A: MRSA harboring mecA variant gene mecC, France. Emerg Infect Dis 2012, 18:1465-1467.

42. Petersen A, Stegger M, Heltberg O, Christensen J, Zeuthen A, Knudsen LK, Urth T, Sorum M, Schouls L, Larsen J, Skov R, Larsen AR: Epidemiology of methicillin-resistant Staphylococcus aureus carrying the novel mecC gene in Denmark corroborates a zoonotic reservoir with transmission to humans. Clin Microbiol Infect 2012, 19:e16-e22

43. Harrison EM, Paterson GK, Holden MT, Larsen J, Stegger M, Larsen AR, Petersen A, Skov RL, Christensen JM, Bak Zeuthen A, Heltberg O, Harris SR, Zadoks RN, Parkhill J, Peacock SJ, Holmes MA: Whole genome sequencing identifies zoonotic transmission of MRSA isolates with the novel mecA homologue mecC. EMBO Mol Med 2013, 5:509-515.

44. Vanderhaeghen W, Vandendriessche S, Crombe F, Nemeghaire S, Dispas M, Denis O, Hermans K, Haesebrouck F, Butaye P: Characterization of methicillin-resistant non-Staphylococcus aureus staphylococci carriage isolates from different bovine populations. J Antimicrob Chemother 2013, 68:300-307.

45. Ibrahem S, Salmenlinna S, Lyytikäinen O, Vaara M, Vuopio-Varkila J: Molecular characterization of methicillin-resistant Staphylococcus epidermidis strains from bacteraemic patients. Clin Microbiol Infect 2008, 14:1020-1027.

46. Tacconelli E, De Angelis G, Cataldo MA, Pozzi E, Cauda R: Does antibiotic exposure increase the risk of methicillin-resistant Staphylococcus aureus (MRSA) isolation? A systematic review and meta-analysis. J Antimicrob Chemother 2008, 61:26-38.

47. Finnish Food Safety Authority Evira and the Permanent working group on antimicrobials of the Ministry of Agriculture and Forestry: Methicillin resistant Staphylococcus aureus-recommendations for the prevention and control of MRSA infection in animals. Helsinki, Finland: Finnish Food Safety Authority Evira, Evira publications 9/2010; 2010.

doi:10.1186/1751-0147-55-61

Cite this article as: Gindonis et al:: Occurrence and characterization of methicillin-resistant staphylococci from bovine mastitis milk samples in Finland. Acta Veterinaria Scandinavica 2013 55:61.

\section{Submit your next manuscript to BioMed Central and take full advantage of:}

- Convenient online submission

- Thorough peer review

- No space constraints or color figure charges

- Immediate publication on acceptance

- Inclusion in PubMed, CAS, Scopus and Google Scholar

- Research which is freely available for redistribution

Submit your manuscript at www.biomedcentral.com/submit
C) BioMed Central 